\title{
THE PROCESS OF SUBURBANISATION IN BABĪTE RURAL MUNICIPALITY AFTER THE YEAR 2000
}

\section{Suburbanizācijas procesi Babītes pagastā pēc 2000. gada}

\author{
Ineta Grīne and Inese Mieze \\ University of Latvia, Faculty of Geography and Earth Sciences \\ Ineta.Grine@lu.Iv
}

\begin{abstract}
Since the year 2000 the population in rural territories surrounding Riga has grown mainly at the expense of migration. These territories have been intensively built up over the past 20 years. As result - many new single-family-house villages have appeared in landscape areas or within the borders of already existing villages. One of the rural municipalities experiencing intensive suburbanisation in its territory after the year 2000 is Babīte parish (a rural municipality), where the population has increased considerably and building of new dwelling houses is rapidly growing, forming new residential districts and new villages. The goal of the present study is to characterise changes in housing in Babite parish (rural municipality) since 2000 under the influence of suburbanisation. The analysis of the present situation proves that Babīte parish has become an attractive place of residence in suburban Rīga with developing housing and a growing population.
\end{abstract}

Keywords: suburbanisation, Rīga area, Babīte parish, villages.

\section{Introduction}

Since the year 2000 in Latvia, many new single-family-house villages have appeared in the outskirts of large cities, close to highways, in landscape areas or within the borders of already existing villages (Grīne and Strautnieks 2012; Grīne and Strautnieks 2018). A typical example is to be found in the rural territories surrounding Rìga, the capital of Latvia. These territories have been intensively built up over the past 20 years. This can be explained not only by the favourable geographical situation, closeness to the main highways and good traffic links from these areas to the capital, but also by good access to public services and a visually attractive landscape. Since 2000 the population in the rural territories surrounding Rìga has grown mainly at the expense of migration - people have moved to the suburban rural territories to live but still work and access public services in town, thus favouring the growth of outskirt migration. Another type of suburbanisation observed in the area is when people (and also companies) move to suburbs where blocks of flats are being built. After the year 2000 the intensity of suburbanisation and migration to the suburban Rìga area has been regulated by housing construction, the housing market and the outreach of jobs (Bērziņ̌s 2011).

One of the rural municipalities experiencing intensive suburbanisation in its territory since 2000 is Babīte parish (rural municipality; pagasts), where the population has increased considerably, and the building of new dwelling houses is rapidly growing, forming new residential districts and new villages.

The aim of the present study is to characterise changes in housing at Babìte parish (rural municipality) after the year 2000 under the influence of suburbanisation. 


\section{Data and Methods}

The principal sources of the present research are:

- published statistical data by the Central Statistical Bureau of Latvia (CSB) about the number and age structure of the population in Babìte parish (rural municipality) and its villages in 2000, 2011, 2016-2018;

- analysis of the cartographical material - orthophotographs of 2013 and 2015, a topographic map (scale 1:10 0000) by the Map browser of the University of Latvia (data source - Geospatial Information Agency of Latvia (LGIA));

- planning documents of the Babīte county - Development Programme of Babīte county for 2014-2020, Sustainable Development Strategy of Babīte county until 2030 and Spatial Planning of Babīte Parish of Riga district from 2008 till 2020;

- public opinion poll results of 2018 (203 respondents), field survey results of 2017-2018. A population survey was undertaken to find out what kind of income levels the residents had gone to live in the Babite parish and their connection with Rịga. The survey included questions about type of housing and year of construction, about residence (reasons for choosing a place to live, satisfaction with the place of residence, future plans for living), as well as questions about workplace, age, income, use of transport by respondents, goals and frequency of visits to Rīga.

\section{Principal Results and Discussion}

Babīte parish with an area of $165.3 \mathrm{sq} . \mathrm{km}$. is situated in the central part of Latvia, bordering with Rīga and the Town of Jūrmala. According to statistical data provided by the Central Statistical Bureau of Latvia (CSB), in 2018 Babīte parish was inhabited by 8977 people, which is approx. $87 \%$ of the population of the Babite county (novads), the density of population being 54.3 people per sq. $\mathrm{km}$. The most part of the territory of Babite parish is covered by agricultural land and forests, a lake and bogs.

The housing of Babīte parish is formed by historically established villages and a network of detached homesteads, as well as new detached houses and villages built during the previous $10-15$ years. At present, Babīte parish comprises 17 villages mainly located not far from the principal highways and the Rīga city border. In some cases the merging of villages has been hindered by natural or artificial obstacles, for instance highway A5 between Pinki and Beberi villages and highway A9 between Dzilnuciems and Skārduciems. In other cases the villages have merged together, so that it is difficult to spot the border between the villages, as is the case with Pinkiki and Sēbruciems or Spilve and Mežāre. The expansion of villages takes place at the expense of agricultural lands. Some new villages have formed closed areas.

Present day housing in the villages reflects the building types of the 1990s, as well as the manner of the first decade of the $21^{\text {st }}$ century. We can see detached single family houses, terraced houses and blocks of flats (Mieze 2018). Up to the year 1999 Babīte, Piņki and Spilve villages were intensively built over. Since 2000 intensive 
construction of new dwellings has been carried out in such villages as Lapsas, Sēbruciems, Vīkuḷi, Dzilnuciems, Priežciems, Mežāre, Spilve (its new part) and Piṇķi (Saliena). The financial crisis affected the intensity of construction works - the most active house building took place until 2008.

Today, new buildings cluster not only around the former residential centres and highways, but also a good way of the highways, as well as next to or even in the forests. Expansion of housing can be seen in such villages as Mežāres, Spilve, Brīvkalni, Sēbruciems, Vīkuḷi, Priežciems, Lapsas and Piṇķi. According to data (Babītes novada attīstības... 2012) in the year 2012 the largest villages by territories occupied were Piņki (659 ha), Spilve (444 ha) and Trenči (378 ha). However, analysis of the cartographical material shows that in 2018 also Mežāres, with a territory of 379 ha belongs to the largest villages. By density of population today the largest villages are Babīte, Piņ̧̧i and Priežciems (Babītes novada attīstības... 2012). With the expansion of housing territories, also the population continues to grow in the villages and in the municipality at large (Figure 1).

After 2000 the population in Babìte parish continued growing. During the period between 2000 and 2018 it has grown by 38.5\% (approx. 3500 people) or, on average, by 200 people a year.

Between 2000 and 2018 the population has grown in all age groups (except in the age group between 15 and 24), and especially in the age group up to 6 . It is worthy of note that in 2018, in every age group (except age groups between 15 to 24 and 55 to 64 ), the number of people exceeded 1000. Thus, in 2018, $16 \%$ of the population of Babìte parish were of the age group between 35 and 44 and $14 \%$ of the age group were between 45 and 54. From 25\% to $34 \%$ is a comparatively large percentage of economically active population.

According to data of the CSB, the population in Babìte parish has grown mainly on account of migration. Between 2000 and 2018 some $48 \%$ of people (2674 individuals) have not changed their place of residence, 1744 have left the area (including emigrants to the EU) and 3817 individuals have newly arrived. The fact that twice as many people have arrived in the rural municipality than have left it has remained constant also between the years 2011 and 2018.

The data of the CSB reveals that in the period between 2000 and 2018 Babite residents have migrated mainly to Rīga, Rīga suburbs (the Mārupe and Kekava counties) and the Town of Jürmala. A similar tendency appears in immigration people have arrived in Babīte parish mainly from Rīga, the Town of Jürmala, and the counties of Jelgava and Mārupe.

This is also confirmed by the survey data. The data from a public opinion poll shows that people arriving in Babīte parish are mainly townspeople from Rīga and Jürmala. They have moved over mostly due to family reasons (approx. 36\%), purchase of housing (approx. 31\%) as well as in search of a more attractive environment (approx. 20\%). Many of them had previously lived in multi-story apartment houses. 
Besides, $90 \%$ of the respondents do not plan to change their place of residence in the nearest future. $10 \%$ of the respondents plan to move to Rìga or abroad.

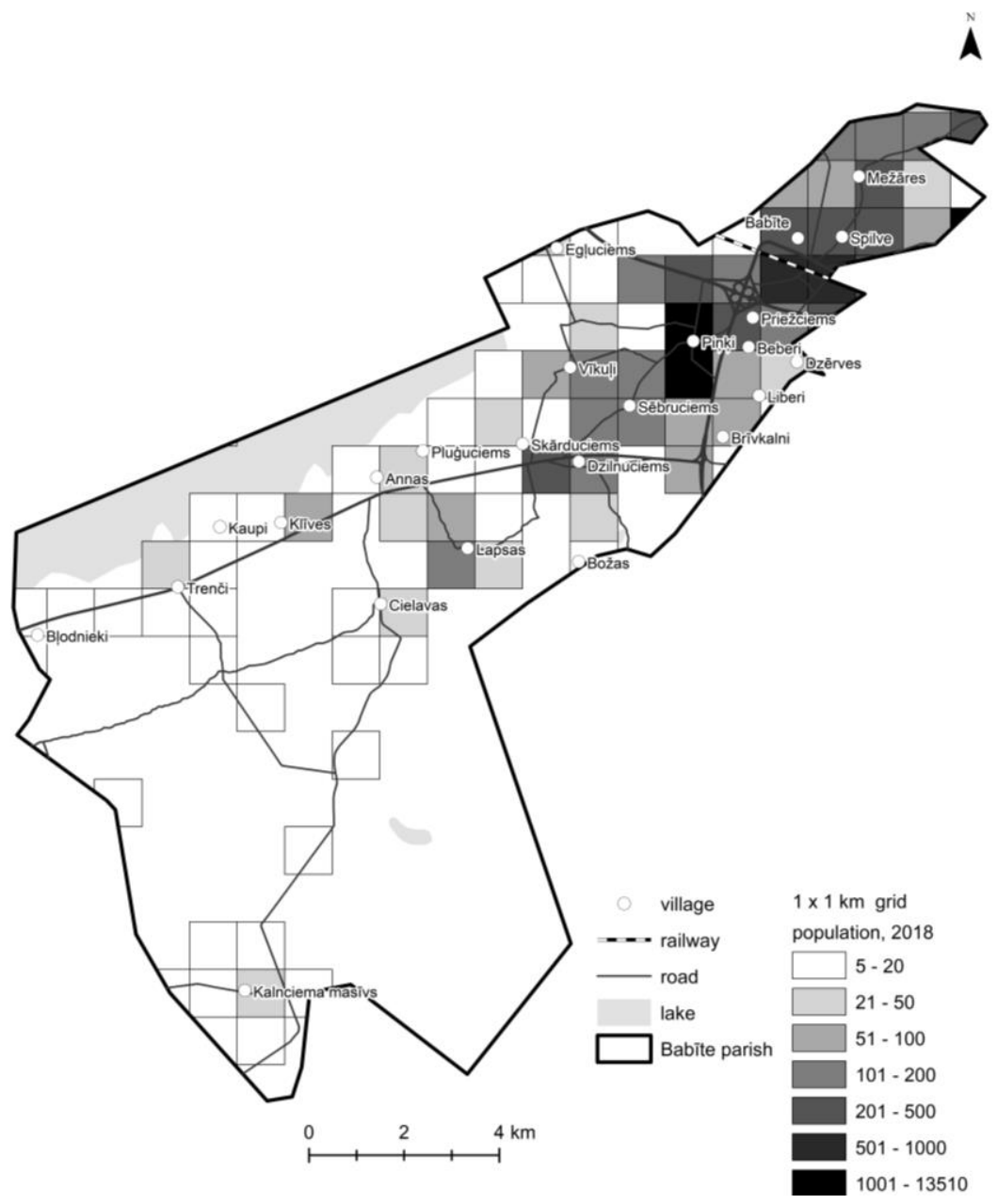

Figure 1. Settlement of Babīte parish, 2018 (authors' figure based on Central Statistical Bureau of Latvia data)

The population has grown mainly in the village areas. More than $95 \%$ of people live in village areas. The proportion of village dwellers has grown from $95 \%$ in 2000 to $97 \%$ in 2018. According to statistical data the largest villages by population are Piņki (3135 people), Babīte (1247 people) and Spilve (1114 people). There are villages, such as Liberi, Dzērves, Cielavas, where the number of population does not exceed 50 people. The greatest growth of population (by more than 400 people) between 2000 and 2018 has been registered in the villages of Mežāre, Spilve and Piņki. The population has also grown in the villages of Priežciems and Sēbruciems by more than 200 people.

Today, out of all inhabitants in Babīte parish $\sim 35 \%$ live in Piņ̧i village, $\sim 14 \%$ in Babite village and $\sim 12 \%$ in Spilve village. It is worthy of note that between 2000 and 2018 the population dropped considerably in Pinķi village (by $\sim 14 \%$ ) and in Babite village (by $\sim 6 \%$ ). It follows that in other villages the number of population has grown, especially in the villages close to the border of Rìga, as, for example, in Mežāres (by $\sim 8 \%$ ) and Spilve (by $\sim 5 \%$ ). This is due to the intensive building of 
detached single-family houses. Already by 2008 it was noted in the documents of spatial planning that Spilve and Mežāre villages are turning into the so-called Rīga "dormitory areas", where people have moved their residences while keeping their jobs in Rìga. The new inhabitants are more linked with Riga than with the village owing to closeness of the city and good traffic (Rīgas rajona Babītes ... 2007/2008). Resident polls also pointed out that choosing Babīte parish as a place of residence - buying a home or building a home - paid attention to the quality of the building, the infrastructure, the availability of schools and kindergartens, the availability of public transport, and the availability of utilities for land (Mieze 2018).

A public opinion poll showed that $95 \%$ of the respondents liked living in the parish. Such an assessment is related to good road infrastructure, good landscapes, accessibility of public transport, sense of security and proximity to Rīga. Some $85 \%$ of the respondents liked the tidy dwelling, 80\% - its environment and $84 \%$ - the neighbours. The respondents who were only partly satisfied or dissatisfied with the environment and dwelling mostly lived in blocks of flats.

The most densely populated area of Babīte parish is its Northern and North Eastern part. It is the territory surrounding the centre of the parish, the Riga border area and the area at the crossing of highways A5 and A10. According to statistical data it is the Eastern territories of Babite parish, especially the area around the Pink, i, Beberi, Babīte, Mežāres and Spilve villages, which have become densely populated between 2000 and 2018 (Figure 1). This can be explained by the process of suburbanisation and development of villages owing to their favourable geographical position, road infrastructure and comparatively good public transport. Most of the respondents either working or studying in Rịga (78\%) commute between the villages and Rīga. The commuters go to Rìga mostly on working days. They usually travel by their own cars $(71 \%)$ and sometimes also by public transport $(26 \%)$. The data from the public opinion poll shows that travelling to Rìga by public transport usually takes from 20 to 40 minutes, sometimes even up to 60 minutes. Travelling from villages close to the Rīga border to Rìga centre by one's own car takes up to 20-40 minutes, sometimes up to 50-60 minutes (as it is from the village of Lapsas). If the job location is either in Mārupe, K,ekava or Jūrmala the respondents mostly commute by their own cars. As the field survey data shows, there is an increasing migration to work and back (Mieze 2018).

As the answers to the public opinion poll showed, the respondents mostly go to Rìga not only because of jobs or studies, but also for shopping, entertainments and medical services. As to access to public services in the parish, the respondent evaluation varied - 36\% of respondents were satisfied, 38\% - were partly satisfied, but $26 \%$ unsatisfied. Respondents also stressed that the lack of services in the rural municipality can be easily replaced with the amenities within Riga. Therefore, as the answers of the public opinion poll showed, the respondents go to Rìga for shopping a few times in the week. 
The respondents who work at the municipality travel to work either by bicycle $(50 \%)$ or by public transport $(38 \%)$. As to the quality of public transport services in Babìte parish, $58 \%$ of the respondents are satisfied, $24 \%$ are partly satisfied but $18 \%$ are dissatisfied. From the group of the respondents who travel to work by public transport $57 \%$ are satisfied with bus services, but from those who travel to work by their own cars $\sim 52 \%$ find public transport services sufficient.

Most of the respondents who travel to Rigga either because of jobs or studies find their income higher than those working at the municipality. $\sim 82 \%$ of the respondents working in Riga earn above the average salary (i.e. 700 EUR), while only $38 \%$ of the respondents working at the municipality earn more than the average salary. The data of the opinion poll also testifies that $\sim 53 \%$ of the respondents are dissatisfied with job opportunities being offered in Babīte parish, while $27 \%$ are only partly satisfied.

Taking into account the public opinion poll, briefly: the characteristics of the respondents from Babīte parish - a short distance to the center of Rìga, the infrastructure development, convenience, good ecological conditions, the availability of forest areas, homogeneous social environment and appropriate property prices (Mieze 2018).

\section{Conclusion}

The analysis of the present situation leads to the conclusion that Babīte parish has become an attractive living space in the Pierīga area - changes in the population are taking place, the number of inhabitants in the parish continues to increase. In Babīte parish there is a characteristic suburbanisation process - the construction of new houses near the Rīga city border, close to the main roads A5, A10, A9, Lake Babīte and forest areas. The construction of new houses is changing the landscape - new individual houses are appearing in the old villages, new villages are being formed. The construction is also related to the return of agricultural land in building territories. In Latvia, there is a tendency for residents to choose their place of residence on the outskirts of the city, as the main reasons are family, housing, work and nature. Babite parish is one of those in which the number of inhabitants in the parish increases mostly at the expense of in-migration from the capital city. The proximity of Riga, the road network and transport options make it easy to reach the city, thus ensuring the possibility of working and providing various services, on the other hand - providing better quality of life and environment - dwelling, nature, calm, recreation.

Babīte county spatial planning documents worked out 5 years ago envisaged further development of Babīte parish by promoting a balanced development of housing, density of population, transport, business, access to public services and attractive environment. The document also envisaged further growth of the population. Thus, Babite parish of 2020 has been planned as a place of residence with properly organised infrastructure suitable for families, but after 2030 - as a fashionable place of residence in Suburban Rīga (Babītes novada ilgtspējīgas ... 2015). 


\title{
Kopsavilkums
}

Iedzīvotāju skaits lauku teritorijās ap Rīgu kopš 2000. gada palielinās galvenokārt migrācijas procesu rezultātā. Intensīva apbūve ir notikusi lauku teritorijās ap Rīgas pilsētu, kas saistās ne tikai ar izdevīgo ǵeogrāfisko stāvokli, galveno autocel̦u tuvumu, labo satiksmi, bet arī ar pakalpojumu pieejamību un sasniedzamību un ainaviski pievilcīgo dzīves telpu. Rezultātā veidojas jauni privātmāju ciemi, kā arī notiek jauno ciemu dal̦ēja saplūšana ar vēsturiskajiem. Viens no pagastiem, kur kopš 2000. gada ir notikušas ievērojamas pārmaiņas apdzīvojumā - palielinājies iedz̄ivotāju skaits, notikusi strauja apbūve, ceḷot jaunas dzīvojamās mājas, veidojot jaunus māju rajonus, jaunus ciemus, ir Babītes pagasts. Šīs pārmaiṇas apdzīvojumā norāda uz intensīvu suburbanizācijas procesu šajā teritorijā. Pētījuma mērkis raksturot pārmaiṇas apdzīvojumā suburbanizācijas procesu ietekmē Babītes pagastā pēc 2000. gada.

\section{References}

Babītes novada attīstības programma 2014.-2020.gadam. Pašreizējās situācijas raksturojums un analīze (2012). http://www.babite.lv/wp-content/uploads/2015/06/I_dala.pdf

Babītes novada ilgtspējīgas attīstības stratēgija līdz 2030. gadam. Stratēǵiskā daḷa un telpiskās attīstības perspektīvas (2015).

content/uploads/2015/07/IAS_Strategiska_dala_apstiprinats.pdf

Bērziṇš, M. (2011). Iekšzemes migrācijas reǵionālās dimensijas Latvijā. Latvijas Zinātṇu Akadēmijas Vēstis, 65 (3/4), 34-54.

Grīne, I. and Strautnieks, I. (2012). Amatciems: example of the creation of a new kind of rural landscape and settlement pattern in Latvia. Latvijas Zinātņu Akadēmijas Vēstis, 66 (3), 156-171.

Grīne, I. and Strautnieks, I. (2018). Apdzīvojuma un ainavas pārmaiņas Amatas ciemā pēc 2000. gada. G̣eogrāfiski raksti. G̣eogrāfija kopīgai nākotnei Latvijas simtgadē. 54-61.

Mieze, I. (2018). Pierīga kā dzīvesvietas izvēle: Babītes pagasta piemērs. Bakalaura darbs. Rīga: Latvijas Universitāte.

Rīgas rajona Babītes pagasta teritorijas plānojums 2008-2020 (2007/2008) I sējums. Paskaidrojuma raksts. http://www.metrum.lv/data/files/teritoriju_attistibas_planosana/Babite/Teksta_dala_gala._red.2008.pdf (28.01.2019.)

\section{DIVERSITY OF GENTRIFICATION IN THE INNER CITIES OF RĪGA AND PRAGUE - THE CASE OF ĀGENSKALNS AND HOLEŠOVICE}

\section{Ģentrifikācijas daudzveidība Rīgas un Prāgas iekšpilsētā - Āgenskalna un Hološovices piemērs}

\author{
Margarita Kairjaka \\ University of Latvia, Faculty of Geography and Earth Sciences \\ mkairjaka@yahoo.com
}

\begin{abstract}
This paper analyses gentrification from two perspectives - cultural consumption and changes in population composition as observed in two inner-city neighbourhoods that are gentrifying, Āgenskalns in Rīga and Holešovice in Prague. Both quantitative and qualitative methods were employed - such as field study and observation, Census data analysis, interview, analysis of reviews on internet platforms, as well as the mapping of results. The study revealed that both neighbourhoods experienced an influx of young and educated residents. It was also concluded that both neighbourhoods experienced major changes in the
\end{abstract}

